JURNAL RESPIRASI

JR

Vol. 5 No. 1 Januari 2019

\title{
Efek Samping Hematologi Akibat Kemoterapi dan Tatalaksananya
}

\author{
Anna Febriani, Yuly Rahmawati \\ Departemen Pulmonologi dan Ilmu Kedokteran Respirasi, Fakultas Kedokteran Universitas Airlangga/RSUD Dr. Soetomo
}

\begin{abstract}
Lung cancer is the leading cause of cancer death in Asia. In Indonesia, it contributes the highest number to cancer incidence in male and is ranked fifth in female cancer incidence. Determinated attempts have been delivered to eliminate cancer with chemotherapy being the most important management strategy for advance stage lung cancer.

As most medicines come with side effects, so does chemotherapy. Beside killing the target cells, the cytotoxic compound of cancer drug may also seriously alter normal cells. Therefore, formidable toxic effect of chemotherapy to normal tissue becomes the main problem, which clinicians should consider. Myelotoxicity is one of the most common chemotherapy-induced adverse events. It takes place in bone marrow-producing regions causing netropenia, thrombocytopenia and anemia. Each of those cytopenias requires separate intervention. This article will review the physiology of hematopoiesis, pathophysiology of cytopenias, and current guidelines and recommendations for prevention and treatment of myelotoxicity of cytotoxic chemotherapy.
\end{abstract}

Keyword: Lung cancer, Adverse event, Myelotoxicity, Management

Correspondence: Anna Febriani, Departemen Pulmonologi dan Ilmu Kedokteran Respirasi, Fakultas Kedokteran Universitas Airlangga/RSUD Dr. Soetomo. Jl. Mayjen. Prof. Dr. Moestopo 6-8 Surabaya 60286. E-mail: febrianianna@gmail.com

\section{PENDAHULUAN}

The International Agency for Research on Cancer (IARC) di bawah naungan WHO menyebutkan dalam data GLOBOCAN 2018 bahwa kanker paru merupakan salah satu jenis kanker dengan kejadian terbanyak dan mempunyai mortalitas tertinggi dibanding jenis lainnya. Kanker paru menyumbang kurang lebih 2,1 juta kasus $(11,6 \%)$ dari total kejadian kanker di seluruh dunia. Kanker paru juga memiliki angka kematian terbesar yaitu 1,8 juta kematian atau $18,4 \%$ dari total kematian karena kanker di seruruh dunia. ${ }^{1}$

Kanker paru merupakan penyebab utama kematian karena kanker di Asia, terutama disebabkan oleh peningkatan konsumsi produk tembakau. Sedangkan peningkatan angka kematian absolut akibat kanker paru di negara maju umumnya disebabkan karena usia tua. ${ }^{2}$ Berdasarkan laporan profil kanker WHO, kanker paru merupakan penyumbang insidens kanker pada laki- laki tertinggi di Indonesia dan merupakan penyumbang kasus ke-5 terbanyak pada perempuan setelah kanker payudara, serviks-uteri, kolorektal, dan ovarium. ${ }^{3}$

Manajemen standar untuk mengatasi kanker paru stadium I sampai III adalah bedah, kemoterapi dan radiasi. ${ }^{4}$ Kemoterapi, baik itu kemoterapi konvensional maupun kemoterapi target, dan imunoterapi, menjadi tatalaksana pilihan untuk stadium IV., ${ }^{4,5}$ Istilah kemoterapi akan merujuk pada kemoterapi konvensional dalam artikel ini. Artikel ini memfokuskan pada pengaruh kemoterapi terhadap sel-sel darah, karena darah rentan terhadap stres oksidatif dan merupakan salah satu sel yang paling terpengaruh oleh kemoterapi.

\section{Kemoterapi Sitotoksik}

Agen kemoterapi sitotoksik terutama bekerja pada fase $\mathrm{S}$ dalam siklus sel, atau saat sintesis DNA. Agen lainnya seperti alkaloid vinka dan taksan, menghambat pembentukan mitotic spindle dalam fase $\mathrm{M}$ (mitosis) siklus sel. Agen-agen ini bekerja paling efektif pada sel yang memasuki fase mitosis, fase paling lemah dalam siklus sel. ${ }^{6}$

Titik kerja agen kemoterapi di dalam DNA tercantum dalam Gambar 1. Sebagian besar agen yang disebutkan berinteraksi dengan DNA atau 


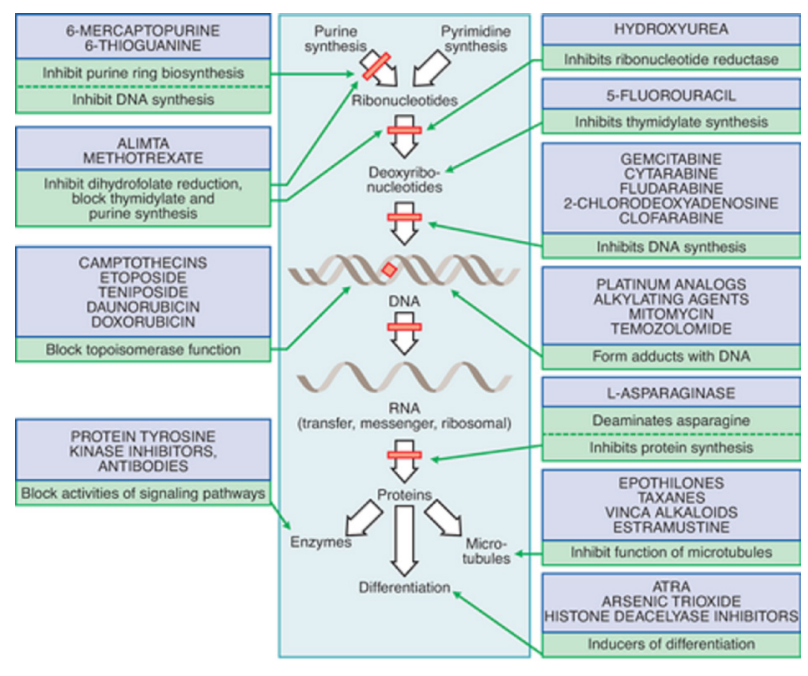

Gambar 1. Mekanisme dan titik kerja beberapa agen kemoterapi ${ }^{6}$

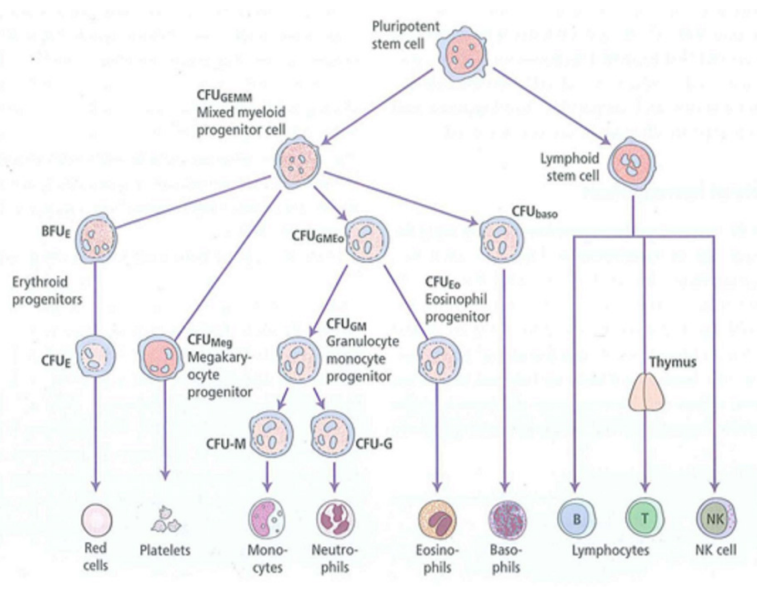

Gambar 2. Skema Hematopoiesis ${ }^{9}$

Tabel. 1 National Cancer Institute Common Terminology Criteria for Adverse Event (CTCAE) ${ }^{12}$

\begin{tabular}{|c|c|c|}
\hline Mielotoksisitas & Definisi & Derajat \\
\hline \multirow{4}{*}{ Anemia } & \multirow{4}{*}{$\begin{array}{l}\text { Suatu gangguan yang ditandai } \\
\text { dengan menurunnya kadar } \\
\text { hemoglobin dalam } 100 \mathrm{~mL} \text { darah }\end{array}$} & Derajat 1: $\mathrm{Hgb}<\mathrm{LLN}-10.0 \mathrm{~g} / \mathrm{dL}$ \\
\hline & & Derajat 2: $\mathrm{Hgb}<10.0-8.0 \mathrm{~g} / \mathrm{dL}$ \\
\hline & & Derajat 3: $\mathrm{Hgb}<8.0 \mathrm{~g} / \mathrm{dL}$, indikasi transfusi \\
\hline & & $\begin{array}{l}\text { Derajat } 4: \mathrm{Hgb}<6.2-4.9 \mathrm{~g} / \mathrm{dL} \text {, mengancam } \\
\text { nyawa, indikasi intervensi segera }\end{array}$ \\
\hline \multirow{4}{*}{ Netropenia } & \multirow{4}{*}{$\begin{array}{l}\text { Temuan hasil laboratorium yang } \\
\text { menunjukkan penurunan jumlah } \\
\text { neutrofil dalam spesimen darah }\end{array}$} & Derajat 1: ANC $<\mathrm{LLN}-1,500 / \mu \mathrm{L}$ \\
\hline & & Derajat 2: ANC $<1,500-1,000 / \mu \mathrm{L}$ \\
\hline & & Derajat 3: ANC $<1,000-500 / \mu \mathrm{L}$ \\
\hline & & Derajat 4: $\mathrm{ANC}<500 / \mu \mathrm{L}$ \\
\hline \multirow{4}{*}{ Trombositopenia } & \multirow{4}{*}{$\begin{array}{l}\text { Temuan hasil laboratorium yang } \\
\text { menunjukkan penurunan jumlah } \\
\text { trombosit dalam spesimen darah }\end{array}$} & Derajat 1: Plt $<$ LLN $-75,000 / \mu \mathrm{L}$ \\
\hline & & Derajat 2: Plt $<75,000-50,000 / \mu \mathrm{L}$ \\
\hline & & Derajat 3: Plt $<50,000-25,000 / \mu \mathrm{L}$ \\
\hline & & Derajat 4: Plt $<25,000 / \mu \mathrm{L}$ \\
\hline
\end{tabular}

prekursornya, menghambat sintesis dari material genetik dan menyebabkan kerusakan luas DNA baik pada sel normal maupun ganas. ${ }^{6}$

Senyawa sitotoksik tidak hanya membunuh sel target, tetapi juga sel-sel normal tubuh. ${ }^{7}$ Terapi target bekerja dengan cara yang berbeda yaitu pada target molekular yang mengatur pertumbuhan atau perkembangan tumor. Target-target ini biasanya berada di dalam sel tumor, walaupun beberapa agen antiangiogenik bisa menyerang sel lain seperti endotel. Cara kerja tersebut membuat terapi target mempunyai spesifisitas tinggi terhadap sel tumor, memberikan rentang terapi yang lebih luas dengan toksisitas lebih sedikit. ${ }^{8}$

\section{Hematopoiesis}

Darah memiliki beragam fungsi, diantaranya transpor gas dan semua zat yang esensial untuk metabolisme sel, pemeliharaan homeostasis, keseimbangan $\mathrm{pH}$, termoregulasi, perantara respons imun, pembuangan zat sisa dan banyak lagi. Darah memerlukan kemampuan regenerasi yang besar untuk menjalankan fungsi-fungsi tersebut,. Sel-sel darah (eritrosit, granulosit dan platelet) diproduksi dengan kecepatan kurang lebih 1-3 juta sel per detik pada orang dewasa sehat. Kemampuan ini menjadikan darah dan sistem hematopoeitik mudah menjadi target bagi obatobat penekan proliferasi sel, seperti pada sebagian besar obat kemoterapi. ${ }^{9}$

Hematopoiesis (dari bahasa Yunani kuno berarti membuat darah) adalah nama ilmiah yang digunakan untuk menjelaskan pembentukan sel darah. Hematopoiesis mempunyai dua cabang utama, yaitu mieloid dan limfoid yang berasal dari stem sel hematopoietik dan menghasilkan bermacam lini sel. Jumlah stem sel hematopoietik diperkirakan hanya ada 1 dalam 20 juta sel berinti di sumsum tulang. ${ }^{10}$ 
Hematopoiesis dimulai dari pembelahan stem sel dimana salah satu sel akan menggantikan stem sel (selfrenewal) dan sel lainnya mengalami proses diferensiasi. Sel-sel progenitor tahap awal ini mengekspresikan sejumlah kecil faktor transkripsi yang dapat mengarahkan sel-sel tersebut menjadi lini sel tertentu. Lini sel mana yang terpilih untuk diferensiasi tergantung dari kesempatan dan sinyal eksternal yang diterima oleh sel progenitor. ${ }^{9}$ Setiap detik, tubuh menghasilkan 2 juta eritrosit, 2 juta platelet dan 700.000 granulosit. $^{10}$

Faktor pertumbuhan hematopoetik diproduksi oleh monosit dan sel stroma sumsum tulang, kecuali eritropoetin yang diproduksi oleh ginjal. Target tujuan adalah titik hematopoietik yang mengikat progenitor hematopoietik melalui reseptor spesifik pada sel endotelial dan osteoblas. ${ }^{10}$

\section{Mielotoksisitas}

Mielotoksisitas adalah efek merugikan dari senyawa toksik terhadap organ pembentuk darah. Obatobatan anti kanker seperti doksorubisin, karboplatin, sisplatin, lenalidomid, talidomid dan vinkristin dikenal luas dapat menyebabkan mielotoksisitas. Tiga jenis mielotoksisitas akibat kemoterapi yaitu netropenia, trombositopenia dan anemia. ${ }^{11}$ Derajat keparahan anemia, netropenia serta trombositopenia yang disebabkan oleh kemoterapi tercantum dalam Tabel 1.

Sebagian besar alkylating agent menyebabkan mielosupresi akut, dengan titik terendah hitung granulosit darah tepi terjadi dalam 6-10 hari dan membaik dalam 14-21 hari. Siklofosfamid mempunyai efek lebih ringan pada hitung platelet darah tepi dibanding agen lain dan dapat menyebabkan efek mielosupresif kumulatif dan menetap selama beberapa bulan atau bahkan tahun. Kamustin dan kloroetilnitrosourea menyebabkan supresi lambat pada platelet dan granulosit, mencapai titik nadir 4-6 minggu setelah pemberian obat kemudian membaik secara perlahan. Sisplatin menyebabkan mielosupresi ringan hingga sedang, menimbulkan netropenia dan trombositopenia transien. Anemia memberat setelah beberapa siklus pengobatan. Efek toksik utama karboplatin yang berpengaruh terhadap penentuan dosis adalah trombositopenia. ${ }^{6}$

\section{Netropenia}

Netropenia akibat kemoterapi adalah salah satu toksisitas utama yang membatasi dosis kemoterapi. Netropenia merupakan masalah klinis yang berakibat negatif pada kualitas hidup, meningkatkan morbiditas dan mortalitas serta biaya perawatan. ${ }^{13}$ Regimen yang mengandung doksorubisin, siklofosfamid dan dosetaksel menyebabkan febrile netropenia pada kurang lebih 30\% pasien. Netropenia berat dapat menyebabkan tertundanya perawatan, kerentanan terhadap infeksi, lamanya perawatan dan kematian. Kejadian dan keparahan netropenia dipengaruhi oleh faktor non genetik, seperti umur, penyakit komorbid, tipe dan stadium kanker begitu juga faktor genetik. ${ }^{14}$

Granulosit dewasa, termasuk neutrofil, mempunyai usia 1-3 hari, sehingga mempunyai tingkat mitosis yang cepat dan lebih rentan terhadap kerusakan sitotoksik dibanding sel meiloid lainnya yang memiliki usia lebih panjang (platelet 10-12 hari, eritrosit 120 hari). Onset dan durasi netropenia berbeda-beda tergantung agen kemoterapi, dosis, frekuensi pemberian, dan faktor inang. Prekursor neutrofil jumlahnya lebih dominan dibandingkan eritroid atau lini sel platelet, yaitu sebanyak $50 \%$ dari keseluruhan sel hematopoietik. ${ }^{15}$

Sel-sel yang membelah secara aktif adalah yang paling sensitif terhadap efek kemoterapi. Derajat sensitivitas dari sel-sel yang berbeda dalam proses pematangan, serta usia setiap lini sel, membantu menjelaskan onset dan perbaikan dari sitopenia dan dasar pemberian faktor pertumbuhan untuk terapi. ${ }^{15}$

Netropenia adalah hitung jenis neutrofil kurang dari $1500 \mathrm{sel} / \mathrm{mm}^{3}{ }^{14}$ Selama kemoterapi sitotoksik, netropenia biasanya terjadi pada titik nadir, yaitu titik terendah hitung neutrofil paska masuknya obat kemoterapi. Hitung sel darah putih mulai menurun pada hari ke-2 sampai ke-3 setelah kemoterapi. Titik nadir biasanya terjadi 10-14 hari setelah kemoterapi di setiap siklusnya. Perbaikan akan terjadi dalam 3 sampai 4 minggu setelah kemoterapi. ${ }^{14,15}$

Demam netropenia adalah suatu sindrom klinis dan diartikan sebagai demam pada pasien dengan ANC $<500 / \mu \mathrm{L}$ atau dengan ANC $1000 / \mu \mathrm{L}$ yang diprediksi akan turun di bawah $500 / \mu \mathrm{L}$ dalam 48 jam setelah onset demam atau tanda sepsis. Gejala klinis seringkali tidak jelas atau minimal pada sebagian besar pasien dengan demam netropenia. Demam tetap terjadi karena sitokin proinflamasi dihasilkan oleh tipe sel lain (makrofag, limfosit, fibroblas, epitel dan endotel). Demam dapat tersamarkan dengan penggunaan kortikosteroid, usia tua dan adanya syok. ${ }^{16}$

\section{Trombositopenia}

Trombositopenia membatasi dosis dan frekuensi kemoterapi disamping risiko perdarahan. Kejadian trombositopenia terkait kemoterapi paling banyak berhubungan dengan pemberian gemsitabin dan regimen berbasis platinum. Setiap agen kemoterapi mempunyai mekanisme yang berbeda dalam menyababkan trombositopenia. Alkylating agents mempengaruhi stem sel, siklofosfamid mempengaruhi megakariosit progenitor yang lebih dewasa, bortezomib mencegah pelepasan platelet dari megakariosit, dan terapi-terapi lainnya memicu apoptosis platelet. ${ }^{17}$

Trombositopenia menimbulkan sejumlah permasalahan dalam perawatan pasien kanker. Risiko perdarahan meningkat pada hitung platelet $<10.000 /$ $\mu \mathrm{L}$ sedangkan pada nilai $<50.000 \mu \mathrm{L}$, perdarahan sering menjadi penyulit prosedur operasi, dan pada nilai $<100.000 \mu \mathrm{L}$, kemoterapi dan radioterapi diberikan dengan pengawasan akan terjadinya trombositopenia dan peningkatan risiko perdarahan. Trombositopenia dapat juga terjadi bersama infeksi atau reaksi obat yang berhubungan dengan terapi kanker. ${ }^{17}$

Platelet dewasa akan mengalami kematian terprogram (apoptosis), bila tidak digunakan dalam hemostasis, yang ditentukan oleh "platelet clock". Platelet clock ini tergantung pada keberadaan protein antiapoptotik yang disebut $\mathrm{Bcl}-\mathrm{x}(\mathrm{L})$, suatu protein yang menghambat protein pro apoptosis Bax dan 
Bak. Aktivitas Bax dan Bak meningkat dan memicu apoptosis platelet saat jumlah $\mathrm{Bcl}-\mathrm{x}(\mathrm{L})$ menurun. Platelet yang sudah diapoptosis dibersihkan oleh sel sistem retikuloendotelial. Sistem limfatik hanya memiliki peran kecil dalam homeostasis normal platelet. ${ }^{17,18}$

Beberapa kemoterapi menurunkan jumlah platelet melalui percepatan penghancurannya. Daya tahan platelet sendiri mungkin terganggu oleh beberapa agen. Etoposide diketahui meningkatkan apoptosis platelet dengan mengurangi aktivitas $\mathrm{Bcl}-\mathrm{x}(\mathrm{L})$. Kemoterapi juga dapat meningkatkan bersihan platelet melalui mekanisme imun, tapi efek ini jarang terjadi. Pemberian agen tunggal fludarabin dalam terapi limfoma diketahui menyebabkan imun trombositopenia pada $4,5 \%$ pasien. Jenis ITP ini biasanya berespon terhadap rituksimab. ${ }^{18}$

\section{Anemia}

Anemia merupakan temuan yang umum pada pasien kanker, dengan persentase kejadian antara 30\%$90 \%$. Penyebab anemia pada pasien kanker antara lain gangguan metabolik dan nutrisi, penyakit kronis, kelainan ginjal, kehilangan darah, penurunan produksi karena penyakit sumsum tulang, penghancuran di perifer karena kelainan autoimun, aplasia sel darah merah yang diinduksi obat, dan anemia akibat kemoterapi. ${ }^{15}$

Anemia akibat kemoterapi jauh lebih sedikit daripada netropenia akibat kemoterapi, karena perbedaan siklus hidup sel darah merah. Kemoterapi dapat menyebabkan anemia melalui mekanisme inhibisi pada hematopoiesis normal dan pada kerja sitokin. ${ }^{19}$ Agen kemoterapi menyebabkan anemia secara langsung degan mengganggu hematopoiesis, termasuk sintesis prekursor sel darah merah di sumsum tulang. Efek nefrotoksik dari agen sitotoksik tertentu (yang mengandung platinum) juga dapat menimbulkan anemia dengan menurunkan produksi eritropoietin. Regimen berbasis platinum, diketahui sebagai penyebab anemia karena efek toksiknya pada sumsum tulang dan ginjal. ${ }^{18,20}$

Efek mielosupresif dari agen sitotoksik tertentu cenderung terakumulasi sepanjang siklus terapi, mengakibatkan perburukan dari anemia seiring bertambahnya siklus kemoterapi. ${ }^{15,19}$ Peningkatan kejadian anemia derajat 2 dan 3 juga berhubungan dengan siklus kemoterapi yang lebih lanjut. Faktor-faktor lain yang dapat dipertimbangkan saat evaluasi risiko anemia akibat kemoterapi yaitu kadar $\mathrm{Hb}$ nadir, waktu yang dibutuhkan untuk mencapai $\mathrm{Hb}$ nadir, dan waktu pengukuran $\mathrm{Hb}$ apakah dilakukan saat sebelum atau sesudah kadar nadir. ${ }^{15}$

Penentuan awal anemia meliputi, pemeriksaan hitung darah lengkap yang juga dapat menunjukkan apakah ada sitopenia lainnya. Hapus darah tepi penting untuk mengkonfirmasi ukuran, bentuk, dan warna sel darah merah. Anamnesis yang rinci dan pemeriksaan fisik harus dilakukan. Anamnesis meliputi durasi dan waktu sampai onset gejala, komorbid, riwayat keluarga dan paparan obat antineoplastik dan radiasi. Keluhan yang umum adalah sinkop, sesak saat aktivitas, sakit kepala, vertigo, nyeri dada, kelelahan (yang mengganggu kerja dan aktivitas harian) dan menstruasi abnormal pada pasien wanita, pucat juga mungkin terlihat. ${ }^{15,20}$ Semua
Tabel 2. Indikasi penggunaan G-CSF dan GM-CSF ${ }^{22}$

\begin{tabular}{cc}
\hline Preventif & Terapi \\
\hline
\end{tabular}

Pada siklus pertama

kemoterapi (pemberian primer)

Afebrile Netropenia

Tidak untuk pemberian rutin

Tidak terbukti bermanfaat

Gunakan bila kemungkinan

terjadi febrile neutropeni

Febrile Netropenia

$>20 \%$

Gunakan bila pasien telah menderita netropenia atau infeksi aktif

Usia $>65$ tahun dengan terapi kuratif untuk limfoma atau tumor lain yang mendapat regimen yang sama

Status Performance rendah sumsum tulang atau darah tepi

Mendapat kemoterapi ekstensif sebelumnya Untuk memobilisasi stem sel dari sumsum tulang

Pada siklus lanjutan bila netropenia terjadi di siklus sebelumnya (pemberian

Untuk mempercepat perbaikan mieloid

sekunder)

Tidak diperlukan pada netropenia onset singkat tanpa Leukemia Mieloid Akut demam

Gunakan bila pasien mengalami febrile netropenia G-CSF hanya sedikit atau tidak di siklus sebelumnya

Gunakan bila netropenia berlangsung lama (walau tanpa demam) dan menunda kemoterapi

GM-CSF tidak bermanfaat dan dapat berbahaya

Sindrom Mielodisplastik

Tidak bermanfaat dalam pemberian rutin

Berikan secara intermiten dalam dosis terbagi pada netropenia dan infeksi

Dosis dan waktu pemberian:

G-CSF: $5 \mathrm{mg} / \mathrm{kg}$ per hari subkutan

GM-CSF: $250 \mathrm{mg} / \mathrm{m} 2$ per hari subkutan

Pegfilgrastim: dosis tunggal 6 mg, 24 jam setelah kemoterapi

Waktu memulai dan mengakhiri terapi :

Bila ada indikasi, mulai dalam 24-72 jam setelah kemoterapi Lanjutkan hingga nilai absolut neutrofi 10.000/uL

Jangan gunakan bersamaan dengan kemoterapi atau radiasi 
penyebab anemia diluar kemoterapi harus diatasi sesuai indikasi. Bila tidak ada penyebab lain yang mungkin, efek inflamasi terkait kanker atau kemoterapi mielosupresif harus dipertimbangkan. ${ }^{15}$

\section{Tatalaksana Netropenia}

Netropenia menjadi predisposisi untuk terjadinya infeksi. Tingkat keparahan dan durasi netropenia, bersama dengan faktor inang dan efek sekunder regimen kemoterapi, berperan dalam timbulnya efek samping yang lebih serius, termasuk demam neutropeni dan bakteriemia. Risiko terbesar dari netropenia akibat kemoterapi, termasuk demam neutropeni, ditemukan dalam siklus pertama kemoterapi. ${ }^{15}$

Secara umum, pemberian profilaksis faktor pertumbuhan mieloid pada populasi risiko tinggi, merupakan tulang punggung terapi netropenia akibat kemoterapi. Keputusan untuk melanjutkan terapi tergantung pada individu, profil risiko pasien termasuk penyakit dasar, regimen terapi, dan ketersediaan pengobatan suportif termasuk faktor pertumbuhan, fasilitas yang terjangkau, sumber finansial, dan dukungan perawatan. Modifikasi atau penundaan dosis mungkin dibutuhkan pada pasien dengan metastase atau penyakit yang sudah tidak dapat disembuhkan yang mungkin membutuhkan perawatan lebih lama. ${ }^{15}$

Beberapa studi menunjukkan bahwa pemberian profilaksis Myeloid Growth Factors (MGFs) dapat mengurangi risiko, keparahan dan durasi demam netropenia. MGFs adalah agen biologis yang mengatur proliferasi, diferensiasi, survival, dan aktifasi sel mieloid. Granulocyte-Colony Stimulating Factor (G-CSF) merupakan jenis MGFs yang menunjukkan hasil baik pada aplikasi klinis. Filgrastim, tbo-filgrastim dan pegfilgrastim adalah G-CSF yang disetujui oleh Food and Drug Administration (FDA) untuk digunakan sebagai profilaksis netropenia akibat kemoterapi. Dosis dan lama pemberian untuk agen-agen tersebut adalah $:^{21}$

1. Filgastrim dan tbo-filgastrim : dosis harian $5 \mathrm{mcg} /$ kgBB subkutan hingga mencapai kadar neutrofil normal atau mendekati normal berdasarkan standar laboratorium. Dimulai 1 hari hingga 3-4 hari setelah akhir kemoterapi dan dilanjutkan sampai nilai neutrofil membaik.

2. Pegfilgrastim : dosis tunggal $6 \mathrm{mg}$ subkutan tiap siklus terapi. Diberikan pada hari ke-1 atau 3-4 hari setelah kemoterapi selesai.

The American Society of Clinical Oncology telah mengembangkan suatu panduan praktik untuk penggunaan G-CSF atau GM-CSF, seperti tercantum dalam Tabel 2 di bawah ini.

\section{Tabel 2. Indikasi penggunaan G-CSF dan GM-CSF 22}

Pasien harus menghindari sebanyak mungkin risiko infeksi. Kebiasaan sehari-hari yang penting dilakukan oleh pasien dengan netropenia yaitu: ${ }^{23}$

1. Mencuci tangan secara teratur, terutama setelah dari toilet

2. Mengindari keramaian dan orang sakit
3. Tidak berbagi barang pribadi seperti sikat gigi, gelas, alat makan atau makanan.

4. Mandi setiap hari

5. Memasak makanan sampai matang

6. Tidak membeli makanan yang kemasannya sudah rusak

7. Membersihkan kulkas dan tidak kelebihan muatan

8. Cuci buah dan sayur dengan baik.

\section{Trombositopenia}

Trombopoetin diharapkan dapat berperan dalam mencegah atau mengatasi trombositopenia pada pasien kanker, seperti peran eritropoetin dan G-CSF dalam mengurangi anemia dan netropenia. Generasi pertama trombopoetin rekombinan menurunkan trombositopenia akibat kemoterapi pada uji klinis awal, tapi perkembangannya terhenti karena munculnya antibodi terhadap trombopoetin endogen. ${ }^{16}$

Secara umum, evaluasi harus dipertimbangkan bila hitung platelet $<100.000 / \mu \mathrm{L}$. Respons terhadap trombositopenia akibat kemoterapi kebanyakan tergantung pada target terapi individual pasien kanker. Penilaian risiko harus diperhitungkan pada pasien dalam tatalaksana terapi kanker atau paliatif. Penilaian klinis akan risiko perdarahan juga penting, terutama bila pasien mendapat obat antikoagulan atau terapi lain yang meningkatkan risiko perdarahan. Tatalaksana yang dapat dilakukan pada trombositopenia akibat kemoterapi adalah sebagai berikut : ${ }^{16}$

- Tangani penyebab lain trombositopenia seperti hentikan antibiotik, atasi infeksi, dan kontrol koagulopati.

- Kurangi dosis dan atau frekuensi kemoterapi atau modifikasi regimen kemoterapi, terutama bila kemoterapi tidak standar dan bukan untuk tujuan kuratif.

- Transfusi platelet dilakukan bila dosis kemoterapi harus dipertahankan untuk mendapatkan respons. Transfusi platelet profilaksis diindikasikan bila terjadi perdarahan atau bila hitung jumlah platelet $<10.000 / \mu \mathrm{L}$ atau $<20.000 / \mu \mathrm{L}$ bila pasien demam.

- Agen antifibrinolitik seperti asam epsilon-aminocaproic atau asam traneksamat telah digunakan pada beberapa pasien trombositopenia untuk mengurangi risiko perdarahan bila transfusi platelet tidak bekerja. Dosis harian 2-24 g asam epsilon-aminocaproic diberikan dalam 3-4 dosis terbagi. Asam traneksamat 4-6mg/hari dalam 3-4 dosis terbagi juga pernah digunakan. Penggunaan dari agen tersebut pada pasien kanker penuh risiko karena agen antifibrinolitik dapat mengeksaserbasi risiko trombosis.

- Trombopoietin reseptor agonis dapat dipertimbangkan pada pasien dengan kontraindikasi transfusi platelet dan pada pasien yang harus mempertahankan dosis kemoterapinya. Romiplostim diberikan pada dosis $2-3 \mu \mathrm{g} / \mathrm{kg}$ tiap minggu, atau eltrombopag $50-75 \mathrm{mg}$ tiap hari 
Tabel 3. Dosis dan Jadwal Pemberian ESA2 ${ }^{6}$

\begin{tabular}{|c|c|c|}
\hline ESA & Tidak Respon & Respon Baik \\
\hline $\begin{array}{l}\text { Epoetin alfa, } \\
150 \text { unit/kgBB } \\
3 \text { kali seminggu } \\
\text { subkutan }\end{array}$ & $\begin{array}{l}\text { Naikkan dosis } \\
\text { epoetin alfa } 300 \\
\text { unit/KgBB } 3 \text { kali } \\
\text { seminggu subkutan }\end{array}$ & $\begin{array}{l}\square \text { Dosis harus disesuaikan } \\
\text { pada setiap pasien untuk } \\
\text { menjaga kadar } \mathrm{Hb} \text { minimal, } \\
\text { cukup untuk menghindari } \\
\text { transfusi }\end{array}$ \\
\hline
\end{tabular}

\section{Epoetin alfa} 40.000 unit 1 kali seminggu subkutan

$$
\begin{aligned}
& \text { Naikkan dosis } \\
& \text { epoetin alfa } 60.000 \\
& \text { unit } 1 \text { kali seming- } \\
& \text { gu subkutan }
\end{aligned}
$$

Atau

Dabopoetin alfa $2,25 \mathrm{mcg} / \mathrm{kgBB}$ 1 kali seminggu subkutan

\section{Naikkan dosis} darbopoetin alfa sampai 4,5 mcg/ kgBB 1 kali seminggu subkutan
Bila $\mathrm{Hb}$ mencapai kadar yang cukup untuk menghindari transfusi atau ada peningkatan $>1 \mathrm{gr} / \mathrm{dL}$ dalam 2 minggu, kurangi dosis epoetin alfa sebanyak $25 \%$ dan darbopoetin alfa sebanyak $40 \%$

Atau

Darbopoetin alfa

500 mcg setiap 3 minggu subkutan

untuk mempertahankan hitung jumlah platelet di atas $100.000 / \mu \mathrm{L}$, dengan tujuan untuk kelanjutan kemoterapi. Trombopoietin reseptor agonis hanya diberikan saat hitung jumlah platelet gagal mencapai $>100.000 / \mu \mathrm{L}$ sebelum jadwal kemoterapi berikutnya.

- Transfusi platelet tidak boleh ditunda saat dibutuhkan karena hitung jumlah platelet baru mulai meningkat 5 hari setelah pemberian trombopoietin reseptor agonis, dengan efek maksimal 10-14 hari kemudian.

- Penggunaan vinkristine, rituksimab, prednison, IVIG, splenektomi atau anti D-immunoglobulin jarang dimanfaatkan pada pasien dengan trombositopenia akibat kemoterapi, walaupun digunakan secara luas dan efektif pada ITP.

- IL-11 rekombinan (oprelvekin) menujukkan manfaatnya dalam menurunkan kebutuhan transfusi platelet pada pasien $96 \%$ yang telah mendapatkan transfusi platelet di siklus sebelumnya dan pada pasien $70 \%$ yang mendapat kemoterapi tambahan. Obat ini telah disetujui FDA untuk mencegah trombositopenia akibat kemoterapi, tapi obat ini mempunyai terlalu banyak efek samping yang membuatnya sulit diterima oleh kebanyakan pasien.

Setiap pasien yang mendapat obat-obatan yang dapat memicu trombositopenia diberi pemahaman mengenai perawatan di rumah seperti menghindari injeksi intramuskular dan subkutan serta menghindari obat-obatan yang dapat bereaksi dengan platelet seperti aspirin, ibuprofen dan obat inflamasi nonsteroid lainnya. $^{21}$

\section{Anemia}

Keputusan untuk melakukan transfusi PRC tidak hanya berdasarkan pada nilai $\mathrm{Hb}$ atau faktor pemicu anemia, namun harus didasarkan pada penilaian individual karakteristik pasien, derajat keparahan anemia, komorbid dan tingkat keparahannya, serta pengalaman klinis dokter. ${ }^{24}$ Pedoman menentukan 3 kategori untuk hal ini: ${ }^{15}$

1. Asimtomatis tanpa komorbid signifikan. Kategori ini membutuhkan observasi dan reevaluasi periodik

2. Asimtomatis dengan komorbid dan risiko tinggi, perlu pertimbangan untuk transfusi.

3. Simtomatik, pasien harus mendapat transfusi Packaged Red Cell (PRC).

Satu unit PRC $(300 \mathrm{~mL})$ memiliki hematokrit $50 \%-80 \%$ dan mengandung $42,5 \mathrm{~g}-80 \mathrm{~g} \mathrm{Hb}$ (dengan 147-278 mg besi) atau $128 \mathrm{~mL}-240 \mathrm{~mL}$ eritrosit murni. Manfaat utama transfusi PRC adalah meningkatkan $\mathrm{Hb}$ dan hematokrit dengan cepat. Transfusi PRC adalah satu-satunya terapi untuk pasien kemoterapi yang membutuhkan koreksi anemia segera. Transfusi 1 unit PRC dapat meningkatkan $\mathrm{Hb}$ sekitar $1 \mathrm{gr} / \mathrm{dL}$ atau hematokrit sebanyak 3\% pada orang dewasa dengan ukuran tubuh standar tanpa perdarahan. Tujuan transfusi secara umum adalah untuk mencegah defisit kapasitas hantaran oksigen ke jaringan. Transfusi jarang dibutuhkan bila kadar Hb lebih dari $10 \mathrm{~g} / \mathrm{dL} .^{24}$

Produksi RBC normalnya dikontrol oleh eritropoietin, suatu sitokin yang diproduksi oleh ginjal. Pemberian Erythropoietin Stimulating Agent (ESA) umumnya merupakan keputusan dalam jangka panjang karena risiko yang ditimbulkannya. ESA merupakan eritropoietin manusia rekombinan sintetik yang dapat merangsang eritropoiesis pada pasien dengan kadar $\mathrm{RBC}$ rendah. Saat ini ada 2 macam ESA yang tersedia di Amerika Serikat yaitu epoetin alfa dan darbepoetin alfa. ESA membutuhkan waktu berminggu-minggu untuk menunjukkan hasil, tetapi efektif untuk mempertahankan kadar $\mathrm{Hb}$ dengan pemberian berulang. Keuntungan utama dari ESA adalah untuk mengurangi kebutuhan transfusi. ${ }^{25}$ NECN telah menetapkan suatu panduan mengenai dosis ESA dan penyesuaiannya berdasarkan respon terhadap pemberian ESA, seperti tercantum dalam tabel 3 di bawah ini.

\section{RINGKASAN}

Kanker paru merupakan penyebab utama kematian karena kanker di Asia. Salah satu upaya tatalaksana untuk stadium yang lebih lanjut seperti stadium IV adalah dengan obat anti kanker paru berupa kemoterapi. Senyawa sitotoksik tidak hanya membunuh sel target, tetapi juga sel-sel normal tubuh. Darah rentan terhadap stres oksidatif dan merupakan salah satu yang paling terpengaruh oleh kemoterapi. Mielotoksisitas adalah efek merugikan dari senyawa toksik terhadap organ pembentuk darah, menyebabkan netropenia, trombositopenia dan anemia. 
Manajemen dari masing-masing netropenia, trombositopenia dan anemia tergantung pada kelainan dasarnya. Beberapa studi menunjukkan bahwa pemberian profilaksis Myeloid Growth Factors (MGFs) dapat bermanfaat untuk netropenia, di samping itu juga perlu tidakan pencegahan risiko infeksi. Beberapa tatalaksana trombositopenia yang dapat dilakukan yaitu pengurangan intensitas kemoterapi atau radiasi, pengurangan dosis regimen penyebab trombositopeni, penghentian terapi, transfusi platelet, pemberian trombopoetin, agen fibrinolitik dan lain-lain. Tatalaksana anemia yang dapat dilakukan yaitu koreksi langsung dengan transfusi PRC, sedangkan untuk jangka panjang dapat diberikan Erythropoietin Stimulating Agent (ESA). Pemilihan cara penatalaksanaan tergantung pada penilaian risiko masingmasing individu pasien.

\section{DAFTAR PUSTAKA}

1. International Agency for Research on Cancer. Latest Global Cancer Data. Geneva: 2018.

2. Didkowska J, Wojciechowska U, Mańczuk M, Łobaszewski J Lung cancer epidemiology : contemporary and future challenges worldwide. Ann Transl Med 2016;4(2):1-11.

3. Komite Penanggulangan Kanker Nasional. Pedoman Nasional Pelayanan Kedokteran: Kanker Paru. Jakarta: Kementrian Kesehatan Republik Indonesia; 2018.

4. Research Institute of Nursing Care for People and Community (RINCPC). Handbook of Self-Managing Side Effects of Chemotherapy in Times of Disaster. In: Disaster Nursing in a Ubiquitous Society Care. Hyogo: University of Hyogo; 2006.

5. Poehlmann J. Comparing Chemotherapy, Targeted Therapy, and Immunotherapy [Internet]. 2018 [cited 2018 Oct 13];Available from: https://lungcancer.net/clinical/comparing-treatments/

6. Chabner BA, Amrein PC, Druker BJ, et al. Chemotherapy of Neoplastic Diseases. In: Brunton L, Chabner B, Knollmann B, editors. Goodman and Gilman's The Pharmacological Basis of Therapeutics. New York: The McGraw-Hill Companies; 2011. p. 1854-1921.

7. Ponzoni M. Liposomal Chemotherapy. Encycl. cancer. 2011;2059.

8. Arora A, Scholar EM. Role of Tyrosine Kinase Inhibitors in Cancer Therapy. J Pharmacol Exp Ther 2005;315(3):971-979.

9. Hoffbrand A, Moss P, Pettit J. Essential Haematology. 5th ed. Victoria: Blackwell Publishing; 2006.

10. Balducci L, Shah B, Zuckerman K. Netropenia and Thrombocytopenia. In: DeVita VT, Lawrence TS, Rosenberg SA, editors. Cancer: Principles and Practice of Oncology. Philadelphia: Wolters Kluwer Health; 2015. p. 1960-1967.
11. Gatti DM, Weber SN, Goodwin NC, Lammert F, Churchill GA. Genetic background influences susceptibility to chemotherapyinduced hematotoxicity. Pharmacogenomics $J$ [Internet] 2017;00(June):1-12. Available from: http://dx.doi.org/10.1038/ tpj.2017.23

12. Common Terminology Criteria for Adverse Events ( CTCAE ). 5.0. US Department of Health and Human Services; 2017.

13. Jin $\mathrm{H}$, Chen $\mathrm{X}, \mathrm{He} \mathrm{W}$, Liu $\mathrm{Q}$, Wei Z, Li J. Risk Factors for Chemotherapy-Induced Leukopenia in Patients with Lung Cancer. Int J Clin Med 2016;7(March):225-230.

14. Shukla P, Singh R. Potential pharmacological interventions against hematotoxicity : an overview. Expert Rev Hematol 2015;1-10.

15. Kurtin S. Myeloid Toxicity of Cancer Treatment. J Adv Pr Oncol 2012;3(4):209-224.

16. Natarajan SK, Narayan S, Yin JAL. Update on the Management of Febrile Netropenia. Eur Oncol Haematol 2011;7(4):263-269.

17. Kuter DJ. Managing Thrombocytopenia Associated With Cancer Chemotherapy. Cancer Netw 2015;29(4):1-11.

18. Silva E De, Kim H. Thrombocytopenia: Focus on platelet apoptosis. Chem Biol Interact [Internet] 2018;284:1-11. Available from: https://doi.org/10.1016/j.cbi.2018.01.015

19. Aldoss IT, Wilson S, Silberstein PT. Chemotherapy-induced Anaemia. 2008;24-26.

20. Lyman G, Glaspy J. Advances in the Management of Chemotherapy-Induced Anemia and Its Treatment. Oncol $J$ 2006;20(8):1517-1525.

21. Myeloid Growth Factors. In: NCCN Clinical Practice Guidelines in Oncology (NCCN Guidelines). National Comprehensive Cancer Network, Inc.; 2014.

22. Sausville E, Longo D. Principles of Cancer Treatment. In: Longo DL, editor. Harrison's Hematology and Oncology. New York: McGraw-Hill Education; 2017. p. 418.

23. Newman BT. What's to know about netropenia? [Internet]. Netropenia Causes, diagnosis, Treat. 2018 [cited 2018 Aug 17];1-8. Available from: https://www.medicalnewstoday.com/ articles/265373.php

24. Rodgers GM, Becker PS, Blinder M, Chanan-Khan A. Cancer- and Chemotherapy- Induced Anemia : Clinical Practice Guidelines in Oncology. J Natl Compr Cancer Netw 2012;10(5):628-653.

25. Kurbatova P, Pujo-menjouet L. Multi-Agent Systems and Blood Cell Formation. In: Modeling, Interactions, Simulations and Case Studies. ResearchGate; 2011. p. 395.

26. Guidelines for the Management of Chemotherapy and Systemic Anticancer Therapy Induced Toxicities Within Primary Care ( Adult solid tumour oncology and Adult haemato-oncology ) “Quality and safety for every patient every time ." In: NECN Guidelines for Community Management of Chemotherapy Toxicity. Gateshead: North of England Cancer Network; 2011. p. $0-21$. 